\title{
PENGARUH PUPUK ORGANIK CAIR BATANG PISANG KEPOK TERHADAP PERTUMBUHAN DAN PRODUKTIVITAS TIGA JENIS TANAMAN SAWI
}

Linna Fitriani ${ }^{1 *}$, Yuni Krisnawati2 ${ }^{2}$, Destien Atmi Arisandy ${ }^{3}$

${ }^{123}$ STKIP PGRI Lubuklinggau, Jl. Mayor Toha Kel. Air Kuti, Lubuklinggau 31626, Indonesia

*Corresponding author, e-mail: linna.fitri@yahoo.com

\section{ABSTRACT}

The purpose of this research is to determine the effect of liquid organic fertilizer of banana stem on the growth and productivity of 3 types of mustard. This type of research is a descriptive quantitative with an experimental method. The study design used a completely randomized design (CRD) with three treatments and eight replications. Data collection by observation using observation sheets. The data obtained were analyzed by analysis of variance (ANOVA) in one path and continued with LSD. Based on the results of the research, there are differences in the effect of giving Liquid Organic Fertilizer to banana stem on the plant height parameters of three types of mustard. The plant height parameters of chinese green cabbage, and collards meat are significantly different from those of green mustard. There are differences in the effect of giving Liquid Organic Fertilizer banana stem to the parameters of the number of leaves of three types of mustard. The parameters of the number of chinese green cabbage and green mustard leaves are significantly different from collards meat. There is a difference in the effect of Liquid Organic Fertilizer on banana stem on the wet weight parameters of three types of mustard. The parameters of wet weight of chinese green cabbage and green mustard are significantly different from collards meat.

Keywords: Liquid Organic Fertilizer, Banana Stem, Growth, Productivity, Mustard

\section{PENDAHULUAN}

Pupuk adalah substansi organik maupun anorganik yang diperlukan tanaman untuk tumbuh dan berkembang (Nisa, 2016). Pupuk merupakan salah satu alternatif yang dapat digunakan para petani dalam meningkatkan hasil pertaniannya, pupuk biasanya berbahan dasar organik yang telah mengalami proses dekomposisi (Nisa, 2016). Pada saat ini, petani masih marak menggunakan pupuk anorganik, hal ini terbukti dari tahun ke tahun penjualan pupuk anorganik selalu mengalami peningkatan (Suwahyono, 2017). Penggunaan pupuk anorganik yang tidak mengikuti prosedur akan menyebabkan tanaman yang ditanam menjadi tidak subur karena menurunnya kualitas fisik, kimia, dan biologis tanah (Oviyanti, dkk, 2016). Jika tidak ditangani sedini mungkin akan menyebabkan kerusakan yang parah pada tanah (Kusumawati, 2015). Mengingat pentingnya tanah bagi tanaman untuk pertumbuhan dan perkembangannya, diperlukan solusi yang efektif.

Solusi yang efektif untuk mengatasi hal tersebut yaitu dengan beralih menggunakan pupuk organik, karena pupuk organik dapat memperbaiki kualitas tanah (Hanum, 2016). Salah Satu pupuk organik yang bisa digunakan adalah Pupuk organik cair batang pisang. Batang sejati atau bonggol pisang memiliki banyak kandungan seperti air, zat besi, fosfor, kalsium, karbohidrat, kalori dan protein, sehingga bonggol pisang bisa dijadikan pupuk organik bagi tanaman (Rukmana, 2001). Mikroorganisme yang terdapat pada MOL bonggol pisang antara lain jenis Bacillus Sp., Aeromonas Sp., Azospirillium Sp., Azotobacter Sp., Aspergillus Nigger dan 
mikroba selulolitik. Mikroba inilah yang dapat membantu pertumbuhan pada tanaman sayuran (Budiyani, dkk., 2016).

Sayuran adalah salah satu komoditas unggul, karena dapat memenuhi kebutuhan sehari-hari. Sayuran memiliki nilai ekonomis dan masa panen yang tidak terlalu panjang (Setyaningrum \& Saparino, 2011). Salah satu sayuran yang banyak dikonsumsi masyarakat adalah sawi. Menurut Samadi (2017), budidaya sawi merupakan bisnis yang sangat menggiurkan, sebab permintaan pasar sangat tinggi. Sawi memiliki beragam jenis (spesies), diantaranya jenis chaisim, jenis sawi pahit dan jenis pakcoy. Sawi caisim merupakan salah satu tanaman kebun pada komoditas sayuran dan bagian yang dimanfaatkan adalah daun-daun yang masih muda yang dapat diolah menjadi ramuan obat tradisional, dan bahan sayuran, sehingga bermanfaat untuk kesehatan manusia (Putri, 2016). Tanaman sawi caisim memiliki beberapa jenis kandungan vitamin seperti folat, karotenoid, dan vitamin A, C, E, dan $\mathrm{K}$ yang bermanfaat untuk kesehatan manusia (Tintondp, 2015).

Sawi pahit dikenal sebagai sawi asin atau sawi hijau, merupakan salah satu komoditas sayuran yang banyak digemari dan memiliki nilai ekonomis yang tinggi. Sayuran sawi pahit digemari oleh semua golongan, karena dapat mempertahankan kesehatan tubuh (Oviyanti, 2016). Sawi pahit memiliki rasa yang khas yaitu ada rasa pahit, walaupun demikian rasa pahit tersebut dapat dihilangkan dengan dijadikan asinan sayuran. Asinan sayuran dapat diolah menjadi sup dan berbagai olahan masakan lainnya (Chooi, 2007). Sawi jenis pakcoy adalah sawi yang saat ini telah banyak dikembangkan oleh petani di Indonesia (Alviani, 2015). Pada tanaman sawi pakcoy banyak terdapat vitamin A sehingga bermanfaat bagi kesehatan mata. Selain itu juga mengandung vitamin $\mathrm{K}$ yang berfungsi untuk pembekuan darah, dan vitamin E yang berperan sebagai antioksidan (Hendra \& Andoko, 2014). Mengingat pentingnya komoditas sayuran, maka produksi tanaman sawi chaisim, sawi pahit dan sawi pakcoy di pasar harus tetap stabil.

Hasil observasi di beberapa pasar, kebutuhan konsumsi sayuran sawi di Kota Lubuklinggau mencapai 8-10 ton/tahun untuk masing-masing jenis sawi. Pemenuhan kebutuhan berbagai jenis tanaman sawi di pasar diperlukan tanah yang subur sehingga hasil produksi tanaman sawi chaisim, sawi pahit dan sawi pakcoy dapat mengalami peningkatan. Untuk meningkatkan produksi tanaman sawi dapat dilakukan dengan memanfaatkan limbah batang pisang menjadi Pupuk Organik Cair. Berdasarkan uraian yang telah dijabarkan, peneliti tertarik untuk melakukan penelitian tentang pengaruh pupuk organik cair batang pisang kepok terhadap pertumbuhan dan produksi tiga jenis sawi.

\section{MET ODE}

Penelitian ini dilaksanakan di Kebun Biologi STKIP PGRI Lubuklinggau dari Juli-November 2018. Alat dan bahan yang digunakan antara lain jaring-jaring, kayu, tali rafia, parang, timbangan, botol, sekop, polybag, tali, mistar plastik, steples, kertas label, botol semprot, alat tulis, kamera ponsel, bibit tanaman sawi tanah, bonggol pisang, gula pasir, air, dan EM-4.

Metode penelitian yang digunakan adalah metode eksprimen dengan menggunakan Rancangan Acak Lengkap (RAL) dengan 1 faktor yaitu Pupuk organik cair batang pisang kepok dengan 3 kelompok perlakuan (tiga jenis sawi) dan 8 pengulangan. Pembuatan pupuk cair dengan menyiapkan tong bertutup yang berisi campuran 3 liter air, 200 gram gula pasir dan EM4 (Effective Microorganism 4) sebanyak $1 / 3$ tutup botol yang digunakan untuk memfermentasikan $1 \mathrm{~kg}$ cincangan 
batang pisang dalam kantung plastik yang sudah diikat. Kemudian menyimpannya pada suhu ruang selama 7-10 hari dan setiap 2 hari sekali tong harus dibuka untuk mengeluarkan gas yang terbentuk.

Penanaman sawi menggunakan hasil semaian yang berusia 4 minggu, kemudian memasukkan ke dalam 24 polibag berukuran $23 \times 23 \mathrm{~cm}$ yang sudah diisi tanah. Pemupukan dilakukan setiap 1 minggu sekali di pagi hari pukul 07.00 WIB atau sore hari pukul 17.00 WIB selama 1 bulan, dengan melarutkan $100 \mathrm{ml}$ Pupuk organik cair batang pisang dengan $1.000 \mathrm{ml}$ air sumur (Rini, 2012). Dosis pemupukan yang diberikan yaitu $60 \mathrm{~mL} /$ tanaman.

Pengukuran tinggi tanaman dilakukan pada umur 1, 2, 3, dan 4 minggu setelah pindah tanam dengan menggunakan benang terlebih dahulu sebelum menggunakan penggaris, Pengamatan jumlah daun dilakukan dengan cara menghitung banyaknya daun yang telah terbuka sempurna setelah tanaman berumur 1, 2, 3, dan 4 minggu setelah pindah tanam. Pengamatan terhadap berat basah dilakukan dengan cara menimbang tanaman yang telah dipanen. Analisis data penelitian dengan Analisis Varians (ANOVA) Satu jalur dengan SPSS versi 16.

\section{HASIL DAN PEMBAHASAN}

Penelitian ini bertujuan untuk mengetahui perbedaan pengaruh pupuk organik cair batang pisang $(60 \mathrm{~mL})$ terhadap tinggi tanaman, jumlah helaian daun, dan berat basah tanaman sawi (chaisim, sawi pahit dan pakcoy).

\section{Tinggi Tanaman Sawi}

Pengukuran tinggi 3 jenis tanaman sawi dimulai sejak 1 minggu setelah tanaman dipindahkan ke polibag sampai tanaman berumur 4 MST (Minggu Setelah Tanam). Data perhitungan jumlah skor, skor tertinggi, skor terendah, rata-rata, std error, simpangan baku, varians tinggi tanaman sawi dapat dilihat pada Tabel 1. Berdasarkan Tabel 1, dapat diketahui rata-rata tinggi tanaman sawi pada umur 1 sampai 4 MST (Minggu Setelah Tanam) pada semua perlakuan, sawi chaisim memiliki rata-rata tertinggi yaitu 13,57 $\mathrm{cm}$ dan terendah pada sawi pahit yaitu 10,35. Selanjutnya tinggi tanaman tersebut dianalisis dengan uji ANOVA satu jalur.

Tabel 1. Tinggi Tanaman Sawi (cm)

\begin{tabular}{cccc}
\hline \multirow{2}{*}{ Perhitungan } & \multicolumn{3}{c}{ Jenis sawi } \\
\cline { 2 - 4 } & Chaisim & Sawi pahit & Pakcoy \\
\hline Tinggi & 22,60 & 10,22 & 23,67 \\
maksimum & & 6,25 & 10,22 \\
Tinggi minimum & 13,57 & 10,35 & 10,57 \\
Rata-rata & 17,82 & 0,86 & 1,22 \\
Std error & 1,97 & 1,7 & 2,4 \\
Simpangan Baku & 3,9 & 3,87 & 3,63 \\
Varians & 3,65 & & \\
\hline
\end{tabular}

Hasil analisis tinggi tanaman diperoleh nilai $\mathrm{F}=19,954$ dengan signifikansi 0,000 (Tabel 2). Hal ini berarti paling tidak ada salah satu kelompok yang rerata lebih tinggi dari yang lainnya perbedaan pengaruh tinggi 3 jenis sawi dilanjutkan dengan uji LSD untuk mengetahui nilai signifikansi tinggi tanaman dari ketiga jenis sawi. Hasil perhitungannya disajikan pada Tabel 3.

Pada Tabel 3, diketahui nilai signifikansi untuk tinggi tanaman sawi chaisim dan tanaman sawi pahit adalah 0,002 yang menunjukkan bahwa adanya perbedaan yang signifikan tinggi tanaman sawi chaisim dan tanaman sawi pahit. berbeda antara 
tanaman sawi chaisim dengan tanaman sawi pakcoy memiliki nilai signifikansi 0,137 yang menunjukkan tinggi tanaman tersebut adalah sama. Nilai signifikansi untuk tinggi tanaman sawi pahit dan tanaman sawi pakcoy adalah 0,000 menunjukkan bahwa adanya perbedaan tinggi tanaman sawi pahit dan tanaman sawi pakcoy.

Tabel 2. Ringkasan Analisis Varians (ANOVA) Satu Jalur Tinggi Tanaman Sawi

\begin{tabular}{cccccc}
\hline $\begin{array}{c}\text { Sumber Adanya } \\
\text { Perbedaan }\end{array}$ & $\begin{array}{c}\text { Jumlah } \\
\text { Kuadrat }\end{array}$ & Df & $\begin{array}{c}\text { Rerata } \\
\text { Kuadrat }\end{array}$ & F & Sig. \\
\hline Antar Kelompok & 328,180 & 2 & 164,090 & & \\
$\begin{array}{c}\text { Inter Kelompok } \\
\text { Total }\end{array}$ & 74,011 & 9 & 8,223 & 19,954 & 0,000 \\
\hline
\end{tabular}

Tabel 3. Uji LSD Tinggi 3 Jenis Tanaman Sawi

\begin{tabular}{cccc}
\hline \multirow{2}{*}{ Chaisim } & Kelompok & Perbedaan Rerata & Sig. \\
\hline \multirow{4}{*}{ Pahit } & tinggi_pahit & $9,06000^{*}$ & 0,002 \\
& tinggi_pakcoy & $-3,31250$ & 0,137 \\
& tinggi_chaisim & $-9,06000^{*}$ & 0,002 \\
& tinggi_pakcoy & $-12,37250^{*}$ & 0,000 \\
& tinggi_chaisim & 3,31250 & 0,137 \\
& tinggi_pahit & $12,37250^{*}$ & 0,000 \\
\hline
\end{tabular}

\section{Jumlah Daun}

Perhitungan jumlah daun 3 jenis tanaman sawi dimulai sejak 1 minggu setelah tanaman dipindahkan ke polibag sampai tanaman berumur 4 MST (Minggu Setelah Tanam). Data perhitungan jumlah skor, skor tertinggi, skor terendah, ratarata, std error, simpangan baku, varians daun 3 jenis sawi dapat dilihat pada Tabel 4.

Tabel 4. Jumlah Daun Pada 3 Jenis Tanaman Sawi

\begin{tabular}{cccc}
\hline \multirow{2}{*}{ Perhitungan } & \multicolumn{3}{c}{ Jenis sawi } \\
\cline { 2 - 4 } & Chaisim & Sawi pahit & Pakcoy \\
\hline Jumlah maksimum & 11 & 7 & 23 \\
Jumlah minimum & 6 & 4 & 9 \\
Rata-rata & 9 & 6 & 16 \\
Std error & 1,04 & 0,64 & 2,93 \\
Simpangan Baku & 2,08 & 1,29 & 5,85 \\
Varians & 4,3 & 1,6 & 34.2 \\
\hline
\end{tabular}

Berdasarkan Tabel 4. dapat diketahui rata-rata jumlah daun tanaman sawi pada umur 1 sampai 4 MST (Minggu Setelah Tanam) pada semua perlakuan, sawi pakcoy memiliki rata-rata tertinggi yaitu 16 helai daun dan terendah pada sawi pahit 6 helai daun. Ringkasan Analisis Varians (ANOVA) satu jalur pada jumlah daun 3 jenis tanaman sawi dapat dilihat pada Tabel 5.

Berdasarkan Tabel 5. diperoleh nilai $F=8,280$ dengan signifikansi 0,009. Hal ini berarti paling tidak ada salah satu kelompok yang rerata lebih tinggi dari yang lainnya. Untuk mengetahui perbedaan pengaruh pemberian pupuk cair organik pisang kepok terhadap 3 jenis sawi dilanjutkan dengan uji LSD, hasil perhitungannya disajikan pada Tabel 6. 
Tabel 5. Ringkasan Analisis Varians (ANOVA) Satu Jalur Jumlah Daun

\begin{tabular}{cccccc}
\hline $\begin{array}{c}\text { Sumber Adanya } \\
\text { Perbedaan }\end{array}$ & $\begin{array}{c}\text { Jumlah } \\
\text { Kuadrat }\end{array}$ & Df & $\begin{array}{c}\text { Rerata } \\
\text { Kuadrat }\end{array}$ & F & Sig. \\
\hline Antar Kelompok & 222,167 & 2 & 111,083 & & \\
Inter Kelompok & 120,750 & 9 & 13,417 & 8,280 & 0,009 \\
Total & 342,917 & 11 & & & \\
\hline
\end{tabular}

Tabel 6. Uji LSD pada Jumlah Daun 3 Jenis Tanaman Sawi

\begin{tabular}{cccc}
\hline \multicolumn{2}{c}{ Kelompok } & $\begin{array}{c}\text { Perbedaan } \\
\text { Rerata }\end{array}$ & Sig. \\
\hline \multirow{2}{*}{ Daun_chaisim } & daun_pahit & 3.00000 & 0.277 \\
& daun_pakcoy & $-7.25000^{*}$ & 0.021 \\
Daun _pahit & daun_caisim & -3.00000 & 0.277 \\
& daun_pakcoy & $-10.25000^{*}$ & 0.003 \\
Daun _pakcoy & daun_caisim & $7.25000^{*}$ & 0.021 \\
& daun_pahit & $10.25000^{*}$ & 0.003 \\
\hline
\end{tabular}

Pada Tabel 6. diketahui nilai signifikansi untuk jumlah daun tanaman sawi chaisim dan tanaman sawi pahit adalah 0,277 yang menunjukkan bahwa tidak adanya perbedaan jumlah daun tanaman sawi chaisim dan tanaman sawi pahit. Berbeda antara tanaman sawi chaisim dengan tanaman sawi pakcoy memiliki nilai signifikansi 0,021 yang menunjukkan Jumlah daun tanaman tersebut adalah berbeda. Nilai signifikansi jumlah daun tanaman sawi pahit dan tanaman sawi pakcoy adalah 0,003 menunjukkan Jumlah daun tanaman tersebut adalah berbeda.

\section{Berat Basah Tanaman Sawi}

Perhitungan berat basah 3 jenis tanaman sawi adalah setelah tanaman di panen. Data perhitungan jumlah skor, skor tertinggi, skor terendah, rata-rata, std error, simpangan baku berat basah 3 jenis tanaman sawi (g) dapat dilihat pada Tabel 7.

Tabel 7. Berat Basah Pada 3 Jenis Tanaman Sawi (g)

\begin{tabular}{cccc}
\hline \multirow{2}{*}{ Perhitungan } & \multicolumn{3}{c}{ Jenis sawi } \\
\cline { 2 - 4 } & Chaisim & Sawi pahit & Pakcoy \\
\hline Berat maksimum & 50 & 50 & 200 \\
Berat minimum & 23 & 10 & 170 \\
Rata-rata & 35,0 & 30,6 & 180,6 \\
Std error & 2,89 & 4,11 & 3,83 \\
Simpangan Baku & 8,17 & 11,6 & 10,83 \\
\hline
\end{tabular}

Berdasarkan Tabel 7, diketahui rata-rata berat basah tanaman sawi pada umur 4 MST (Minggu Setelah Tanam) pada semua perlakuan, sawi pakcoy memiliki ratarata berat basah tertinggi yaitu 180,6 g dan terendah pada sawi pahit 10 gram. Selanjutnya diuji dengan ANOVA satu jalur. Ringkasan Analisis Varians (ANOVA) satu jalur pada berat basah 3 jenis tanaman sawi dapat dilihat pada Tabel 8.

Berdasarkan Tabel 8. diperoleh nilai $\mathrm{F}=547,122$ dengan signifikansi 0, 000. Hal ini berarti paling tidak ada salah satu kelompok yang rerata lebih tinggi dari yang lainnya. Untuk mengetahui perbedaan pengaruh pemberian pupuk cair organik pisang kepok terhadap berat basah 3 jenis sawi dilanjutkan dengan uji LSD, hasil perhitungannya disajikan pada Tabel 9. 
Tabel 8. Ringkasan Analisis Varians (ANOVA) Satu Jalur Berat Basah 3 Jenis Tanaman Sawi

\begin{tabular}{cccccc}
\hline $\begin{array}{c}\text { Sumber Adanya } \\
\text { Perbedaan }\end{array}$ & Jumlah Kuadrat & Df & $\begin{array}{c}\text { Rerata } \\
\text { Kuadrat }\end{array}$ & F & Sig. \\
\hline Antar Kelompok & 116602,083 & 2 & 58301,042 & & \\
Inter Kelompok & 2237,750 & 21 & 106,560 & 547,122 & 0,000 \\
Total & 118839,833 & 23 & & & \\
\hline
\end{tabular}

Tabel 9. Uji LSD Berat Basah pada3 Jenis Tanaman Sawi

\begin{tabular}{cccc}
\hline \multicolumn{2}{c}{ Kelompok } & Perbedaan Rerata & Sig. \\
\hline berat_caisim & berat_pahit & 4,37500 & 0,406 \\
& berat_pakcoy & $-145,62500^{*}$ & 0,000 \\
berat_pahit & berat_caisim & $-4,37500$ & 0,406 \\
& berat_pakcoy & $-150,00000^{*}$ & 0,000 \\
berat_pakcoy & berat_caisim & $145,62500^{*}$ & 0,000 \\
& berat_pahit & $150,00000^{*}$ & 0,000 \\
\hline
\end{tabular}

Pada Tabel 9. diketahui nilai signifikansi untuk berat basah tanaman sawi chaisim dan tanaman sawi pahit adalah 0,406 yang menunjukkan bahwa tidak adanya perbedaan berat basah tanaman sawi chaisim dan tanaman sawi pahit. berbeda antara tanaman sawi chaisim dengan tanaman sawi pakcoy memiliki nilai signifikansi 0,000 yang menunjukkan berat basah tanaman tersebut adalah berbeda. Nilai signifikansi yang sama juga berat basah antara antara tanaman sawi pahit dengan tanaman sawi pakcoy.

Berdasarkan Tabel 2, 6 dan 9 terdapat pengaruh pupuk organik cair batang pisang terhadap tinggi, jumlah dan berat basah tanaman sawi chaisim, tanaman sawi pahit, dan tanaman sawi pakcoy. Tanaman sawi yang memiliki tinggi tanaman tertinggi, jumlah dan terbanyak dan berat basah terbesar secara berurutan adalah sawi pakcoy, diikuti oleh sawi chaisim, kemudian terakhir sawi pahit. Hujan yang tidak teratur dan terus menerus pada saat penelitian telah menyebabkan tanaman roboh dan menyebabkan akar tanaman sawi pahit menjadi busuk. Hal tersebut didukung oleh penelitian Alam, dkk (2012) yang menyatakan bahwa perubahan cuaca yang tidak teratur (tidak menentu) berdampak negatif pada pertumbuhan dan perkembangan tanaman.

Berdasarkan hasil pengamatan tanaman sawi jenis pakcoy lebih tahan terhadap curah hujan yang terus-menerus. Hal ini selain dipengaruhi oleh pupuk organik cair yang diberikan, juga dipengaruhi morfologi daunnya yang menjulang dan kokoh dibandingkan dengan jenis sawi lainnya sehingga terlindungi dari patahan dan genangan air pada saat hujan. Hal ini sesuai dengan pendapat Prihmantoro (2004) bahwa unsur $\mathrm{K}$ pada pupuk oganik cair diperlukan untuk memperkuat tubuh tanaman. Hal ini juga sesuai dengan pendapat Ibrahim (2015) bahwa unsur makro yang terdapat pada Pupuk organik cair batang pisang adalah kalsium (Ca), sulfur (S), air, protein, dan karbohidrat.

Pemberian Pupuk organik cair batang pisang sangat berperan penting terhadap aktivitas fotosintesis tanaman sawi. Karena Pupuk organik cair batang pisang mengandung unsur sulfur (S) yang berperan menstabilkan nitrogen (N) dan membantu proses sintesis klorofil (Rizkika, 2015). Meningkatnya aktivitas fotosintesis akan menghasilkan energi dan nutrisi yang cukup bagi tanaman sawi, sehingga akan mempengaruhi pertumbuhan tinggi dan jumlah helaian daun tanaman 
sawi. Kekurangan unsur N (nitrogen) dan $\mathrm{P}$ (fosfor) menyebabkan terhambatnya pertumbuhan, rendahnya hasil produksi, dan kualitas dari tanaman sawi (Rizkika, 2015).

Selain itu, kekurangan unsur K (kalium) juga menyebabkan tanaman menjadi tidak kokoh sehingga tidak bisa mempertahankan jumlah daun agar tidak gugur (Suprihatin, 2011). Unsur Ca (kalsium) juga dibutuhkan tanaman sawi untuk membentuk struktur dinding sel dan mengatur pengambilan nutrisi (Rizkika, 2015). Kekurangan unsur Ca (kalsium) juga akan menghambat pembentukan struktur dinding sel, menghambat pengambilan nutrisi, menghambat terbentuknya bulu-bulu akar (Prihmantoro \& Indriani, 2017). Kekurangan unsur sulfur (S) dapat menyebabkan unsur nitrogen tidak stabil, proses sintesis klorofil menjadi terhambat, dan menghambat dalam proses pembentukan gula dan pati (Rizkika, 2015). Hal ini sesuai dengan penelitian Cahyono (2003), bahwa berat basah sangat dipengaruhi oleh penyerapan unsur hara dan penimbunan hasil fotosintesis dalam tumbuhan.

Berdasarkan pengukuran suhu yang telah dilakukan selama penelitian di Kebun Biologi STKIP PGRI Lubuklinggau, tercatat suhu yang dihasilkan sebesar $25^{\circ} \mathrm{C}$ sampai $32^{\circ} \mathrm{C}$. Suhu ini masih berada diantara suhu minimum dan suhu maksimum syarat hidupnya tanaman. Namun, perubahan suhu yang tidak teratur menyebabkan pertumbuhan tinggi tanaman sawi pahit menjadi terhambat dan daunnya menggulung. Sedangkan pada jenis sawi pakcoy dan sawi chaisim lebih tahan. Terhambatnya pertumbuhan tinggi dan menggulungnya tanaman disebabkan karena terhambatnya proses fotosintesis dan respirasi pada tanaman sawi pahit karena kurangnya cahaya optimum yang dibutuhkan tanaman (Raharjeng, 2015). Terhambatnya proses tersebut berdampak pada kurangnya penyerapan nutrisi dari dalam tanah dan terhambatnya proses transportasi nutrisi yang dibutuhkan tanaman (Maghfiroh, 2017).

Faktor lain yang mempengaruhi petumbuhan dan perkembangan tanaman sawi adalah suhu dan hama (seperti belalang, ulat gerayak, dan bekicot kecil). Suhu minimum-maksimm tanaman berkisar pada suhu $4,5^{\circ} \mathrm{C}$ sampai $36^{\circ} \mathrm{C}$ (Zulkarnain, 2010). Berdasarkan hasil pengukuran suhu dengan menggunakan termometer di kebun Biologi STKIP PGRI Lubuklinggau diperoleh suhu kisaran $25-32^{\circ} \mathrm{C}$. Pengukuran pH (kadar keasaman tanah) juga sesuai dengan syarat hidup pertumbuhan tanaman sawi.

\section{SIMPULAN}

Berdasarkan hasil penelitian dapat disimpulkan terdapat perbedaan pengaruh pemberian pupuk organik cair batang pisang kepok terhadap parameter tinggi tiga jenis tanaman sawi. Paramater tinggi tanaman sawi chaisim, sawi pakcoy secara signifikan berbeda dengan tanaman sawi pahit. Terdapat perbedaan pengaruh pemberian pupuk organik cair batang pisang kepok terhadap paramater jumlah daun tiga jenis tanaman sawi. Parameter Jumlah daun sawi chaisim dan sawi pahit secara signifikan berbeda dengan sawi pakcoy. Terdapat perbedaan pengaruh pemberian pupuk organik cair batang pisang Kepok terhadap paramater berat basah tiga jenis tanaman sawi. Parameter berat basah sawi chaisim dan sawi pahit secara signifikan berbeda dengan sawi pakcoy.

\section{UCAPAN TERIMAKASIH}

Kami mengucapkan terimakasih kepada semua pihak yang telah membantu penyelesaian penelitian ini terutama kepada STKIP-PGRI Lubuklinggau yang telah 
mendanai penelitian beserta memberikan kemudahan-kemudahan dalam perizinan dan penggunaan lahan untuk penelitian.

\section{REFERENSI}

Alam, A.R.S., Aryadi, M., Biyatmoko, D., \& Satriadi, T. (2012). Persepsi dan Makna Perubahan Iklim Terhadap Usaha Pertanian Studi Kasus di Desa Sungai Rangas Tengah Kabupaten Banjar. Jurnal Enviro Scienteae, 8(3):7-15.

Alviani, P. (2015). Bertanam Hidroponik untuk Pemula. Pondok Kelapa: Bibit Publisher.

Budiyani, N,K., Soniari N.N., \& Sutari, N.W.S. (2016). Analisis Kualitas Larutan Mikroorganisme Lokal (MOL) bonggol Pisang. E-Jurnal Agroekoteknologi Tropika, 5(1), 63-72.

Cahyono, B. (2003). Teknik dan Strategi Budi Daya Sawi Hijau. Yogyakarta: Yayasan Pustaka Nusatama.

Chooi, 0. H. (2007). Sayuran Khasiat dan Ubatan. Kuala Lumpur: Data Pengkatalongan.

Hanum, H., Guchi H., \& Jamilah. (2016). Pengaruh Pupuk Anorganik dan Organik Terhadap Sifat Kimia Tanah di Lahan Sawah dengan Sistem Tanam SRI dan Konvensional. Prosiding Seminar Nasional Lahan Suboptimal, intensifikasi Produksi Pangan Berkelanjutan di Lahan Basah Tropis, Palembang. Palembang: Pusat Unggulan Riset Pengembangan Lahan Sub Optimal Univesitas Sriwijaya.

Hendra, H. A. \& Andoko, A. (2014). Bertanam Sayuran Hidroponik Ala Paktani Hydrofarm. Jakarta: AgroMedia.

Ibrahim. (2015). Pembuatan Pupuk Kompos dari Limbah Batang Pisang (Musa paradisiaca linn) dan Pupuk Kotoran Sapi dengan Effective Mikroorganisme $\left(E M_{4}\right)$. Diakses dari http://docobook.com/queue/pembua-tan-pupuk-komposdari limbah-batang-pisang.html.

Kusumawati, A. (2015). Analisa Karakteristik Pupuk Kompos Berbahan Batang Pisang. Prosiding Seminar Nasional Universitas PGRI Yogyakarta, Peran RISTEK dalam Meningkatkan Daya Saing Bangsa di Era Global. Yogyakarta: Universitas PGRI Yogyakarta.

Maghfiroh, J. (2017). Pengaruh Intesitas Cahaya Terhadap Pertumbuhan Tanaman. Prosiding Seminar Nasional Pendidikan Biologi. Yogyakarta: Universitas Negeri Yogyakarta.

Nisa, K. (2016). Memproduksi Kompos \& Mikro Organisme Lokal (MOL). Jakarta: Bibit Publisher.

Oviyanti, F. (2016). Pengaruh Pemberian Pupuk organik cair Daun Gamal (Gliricidia sepium (Jacq.) Kunth ex Walp. Terhadap Pertumbuhan Tanaman Sawi Pahit (Brassica juncea L.). Jurnal Biota, 2(1): 61-67.

Putri, U. (2016). Kiat Sukses Usaha Budidaya Sawi. Yogyakarta: Lumenta Publishing.

Prihmantoro, H., \& Indriani, Y. H. (2017). Petunjuk Praktis Memupuk Tanaman Buah. Depok: Penebar Swadaya.

Raharjeng, A., R., P. (2015). Pengaruh Faktor Abiotik Terhadap Hubungan Kekerabatan Tanaman Sansevieria trifasciata L. Jurnal Biota, 1(1): 33-41.

Riskika, K. (2015). Hidroponik Tanpa Atap. Jakarta: PT. Trubus Swadaya.

Rukmana, R. (2001). Aneka Olahan Limbah: Tanaman Pisang, Jambu Mete, Rossela. Yogyakarta: Kanisius.

Samadi, B. (2017). Teknik Budidaya Sawi dan Pak Choy. Jakarta: Pustaka Mina. 
Setyaningrum, H. D. \& Saparino, C. (2011). Panen Sayur Secara Rutin di Lahan Sempit. Jakarta: Penebar Swadaya.

Suprihatin. (2011). Production Process of Liquid Fertiliser From Banana Trunk (Proses Pembuatan Pupuk Cair dari Batang Pohon Pisang). Jurnal Teknik Kimia, 5(2): 429-433.

Suwahyono, U. (2017). Panduan Penggunaan Pupuk Organik. Jakarta: Penebar Swadaya.

Tintondp. (2015). Hidroponik Wick System Cara Paling Praktis Pasti Panen. Jakarta: AgroMedia Pustaka.

Zulkarnain. (2010). Dasar-dasar Hortikultura. Jakarta: Bumi Aksara. 